\title{
WHAT DO WE KNOW ABOUT THE CAPITAL STRUCTURE OF SMALL FIRMS?
}

\author{
Karin Jõeveer
}
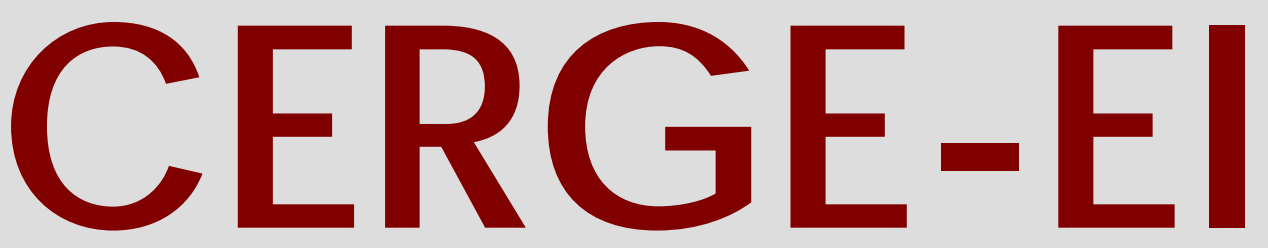

Charles University Centerfor Ec onomic Research and Graduate Educ ation Academy of Sciences of the Czech Republic Ec onomic Institute 


\title{
Working Paper Series 283 (ISSN 1211-3298)
}

\section{What Do We Know about the Capital Structure of Small Firms?}

\author{
Karin Jõeveer
}

CERGE-EI

Prague, December 2005 
ISBN 80-7343-077-0 (Univerzita Karlova v Praze, CERGE)

ISBN 80-7344-066-0 (Národohospodářský ústav AV ČR, Praha) 


\title{
What Do We Know about the Capital Structure of Small Firms?
}

\author{
Karin Jõeveer*
}

November 2005

\begin{abstract}
There are no stylized facts about the capital structure of small firms. Therefore, in this paper I use firm data from 10 Western European countries to contrast the sources of leverage across small and large firms. Specifically, I jointly evaluate the explanatory power of firm-specific, country of incorporation institutional, and macroeconomic factors. Using data that is more comprehensive in coverage than that used in the existing research, I confirm the stylized facts of the capital structure literature for large and listed firms, but I obtain contrasting evidence for smaller companies: First, the country of incorporation carries much more information for small firms supporting the idea that small firms are more financially constrained and face non-firm-specific hurdles in their capital structure choice. Second, using two different leverage measures I show that the relationship of firm size and tangibility to leverage is robust to the measure used for listed, but not for unlisted, firms.
\end{abstract}

\begin{abstract}
Abstrakt
V současné době neexistují obecně uznávaná fakta o kapitálové struktuře malých firem. $\mathrm{Z}$ tohoto důvodu zkoumám data $\mathrm{z}$ deseti západoevropských zemí a porovnávám zdroje zadluženosti malých a velkých firem. Jmenovitě jsem se zaměřila na vyhodnocení vysvětlující síly souběžného působení firemních a lokačně-specifických institucionálních a makroekonomických faktorů. Při použití dat, která jsou mnohem obsáhlejší než nabízí dosavadní výzkum, potvrzuji stylizovaná fakta z literatury o kapitálové struktuře pouze $\mathrm{v}$ prrípadě velkých a kótovaných firem. Na druhé straně vyvozuji opačné závěry u malých firem. $\mathrm{V}$ případě malých firem nese země lokace firmy více informací než u velkých firem, což je v souladu s myšlenkou, že malé firmy jsou více finančně limitované a že čelí firemně nespecifickým překážkám při volbě své kapitálové struktury. Dále ukazuji pomocí aplikace dvou odlišných měr podnikové zadluženosti, že vztah mezi zadlužeností a velikostí firmy je robustní k použité míře pouze pro kótované firmy, nikoli pro nekótované.
\end{abstract}

JEL classification: G32

Keywords: Capital structure, Publicly traded and privately hold companies, Europe.

* I am indebted to Stepan Jurajda for many valuable discussions and comments. I thank Ron Anderson and Jan Svejnar for their helpful comments. The paper was written while I was visiting the William Davidson Institute (WDI), University of Michigan Business School. I would like to thank WDI for their hospitality and data access. I gratefully acknowledge financial support from CERGE-EI.

CERGE-EI is a joint workplace of the Center for Economic Research and Graduate Education, Charles University, and the Economics Institute of the Academy of Sciences of the Czech Republic.

Address: CERGE-EI, P.O. Box 882, Politických věznů 7, Prague 1, 111 21, Czech Republic.

E-mail: karin.joeveer@cerge-ei.cz 


\section{Introduction}

Ten years ago Rajan and Zingales (1995) wrote a pioneering empirical capital structure study using international data. Since then the research in the field has multiplied but the evidence provided is based on large listed companies. ${ }^{1}$ In the present study I examine whether the capital structure findings from large companies are portable for small companies.

Differences between large and small firms have been pointed out in the firm growth literature. Evans (1987) shows that small firms have higher growth rates than large firms. More relevant to the study of capital structure, Carpenter and Petersen (2002) show that the growth of small firms is constrained by internal finance. Therefore, it appears very important to explore the capital structure of small firms as well as large firms. Small firms are huge, when taken as a whole. The European Commission and Eurostat (2001, page 15) claim that firms with less than 250 employees account for twothirds of all jobs and about half of the turnover of the non-agricultural sector in the European Union.

Based on theoretical capital structure studies we know that firm capital structure emerges from three sources: firm specific, country institutional, and macroeconomic factors. $^{2}$ The implications of theoretical studies have been tested in numerous empirical

\footnotetext{
${ }^{1}$ This is largely due to data availability. Stock market-listed firms are required to report annual financial records by law, and usually the accounting standards for those firms across countries are the same.

${ }^{2}$ For example, Harris and Raviv's (1990) agency cost model shows that leverage is positively related to firm value and liquidation value, and Myers (1977) points out the importance of firm growth opportunities. In Modigliani and Miller's (1963) trade-off theory, firms trade off the benefits from tax shields of debt with potential bankruptcy costs. Hence, the tax rate is considered an important determinant of
} 
studies. The most attention has been focused on the estimation of leverage on firmspecific characteristics (Bradley, Jarrell, and Kim 1984; Titman and Wessel 1988). The latest study, based on US firms (Frank and Goyal 2004), has found that firm characteristics explain approximately $30 \%$ of within-country firm leverage variation. Among firm variables, industry is a significant determinant of leverage. Industry alone has been found to explain up to $25 \%$ of within-country leverage variation (Bradley, Jarrell, and Kim 1984). Korajczyk and Levy (2003) show that for US firms, macroeconomic variables can explain as high a share of leverage variation as firm factors. A cross-country capital structure study by Booth, Aivazian, Demirgüç-Kunt, and Maksimovic (2001) find that country dummies explain $43 \%$ of firm leverage variation in a sample of ten developing countries during the period 1980-90. In more detail, Desai, Foley, and Hines (2004) show that the country tax rate explains the firm leverage level in different countries. Hence, there is empirical evidence for the importance of all three - firm, institutional, and macroeconomic - factors in determining firm capital structure. However, there is still a lack of studies spanning a large number of countries and different firm types simultaneously.

In this paper, I study both the effects of firm and country factors on small as well as on large firm leverage. This is important from two perspectives. First, I manage to quantify the relative importance of different sources across firm size. Second, I overcome the possible omitted variable biases by including simultaneously factors from different sources.

firm leverage as is the legal and administrative costs of bankruptcy. Jensen and Meckling (1976) stress the importance of investor protection in a country. Finally, Levy (2001) spells out the importance of domestic macroeconomic factors. 
In my study, I use firm data from ten Western European countries. This data set has a number of attractive features for studying the determinants of capital structure. First, the firm coverage of my sample is well-balanced across firm sizes and industries. Second, my sample includes countries that have not yet been studied. Third, I use recent data (1995-2002).

I perform the analysis by using two different leverage measures. First, I use the broadest definition of leverage - the total liabilities to total assets ratio. Second, I use a narrower leverage definition - the total debt over debt plus shareholders funds ratio. The results are sensitive to the measure of leverage used for unlisted firms but not for listed firms. The mean unlisted firm is much smaller than the mean listed firm, 18 and 432 employees, respectively.

I use analysis of variance (ANOVA) to answer the question of the relative importance of different sources (firm and country characteristics) for explaining firm leverage. I show that the influence of the factors on firm leverage differs across firm types. In particular, country factors are less important determinants of capital structure for large firms than for small firms. This finding is in accord with Holmstrom and Tirole's (1997) prediction that small firms face stricter constraints in achieving external finance, and hence, the domestic macroeconomic and institutional factors contribute more to the determination of leverage. Large firms are more likely (Claessens, Klingebiel, and Schmukler 2003) to cross-list in international equity markets, confirming that for those firms the domestic financial market situation is less important. In a richer model, I add, along with country dummies, a set of country-specific variables known in the literature to explain firm leverage. Even after controlling for observable country variables, the country dummies still explain $11 \%$ of leverage variation for listed firms and $25 \%$ for unlisted firms. This 
finding suggests that there are significant (unobservable) institutional differences across countries explaining firm leverage.

In the last part of my analysis, I estimate a leverage regression on pooled crosscountry data. I include in the regression firm-specific variables, country factors, and country and year dummies. Regressions with narrow leverage as a dependent variable produce consistent results across listed and unlisted firms. Coefficients of firm-specific factors have the same signs as in previous capital structure studies. Interestingly the signs are different for tangibility and size in the unlisted firm broad leverage regression. The main difference between my leverage definitions is that the narrow leverage does not include trade credit and other short-term non-debt liabilities. These items cover a large share of unlisted firm liabilities. Still, I show that the larger share of those items does not explain the different signs in leverage regressions.

In addition to the existing capital structure literature, my study is also related to several research areas in the field of corporate finance and industrial organization. First, it is closely connected to the literature on financial constraints and external finance dependence. Second, it is related to the firm growth and firm size distribution literature. Third, the stock market returns literature, which explores the significance of firm, industry and country characteristics in explaining stock returns, is also linked to the leverage of listed firms. ${ }^{3}$

This paper is organized as follows: In the next section, I briefly review the relevant

\footnotetext{
${ }^{3}$ Morck, Yeung, and Yu (2000) show that stock prices move together more in poor economies than in rich ones - country factors matter more for firm stock price in poor markets. Cambell, Lettau, Malkiel, and $\mathrm{Xu}$ (2001) show that in the US, firm-specific factors gained importance over market factors during 1967-97. Hence, it would be interesting to analyse how the importance of firm, industry and country effects has changed in terms of firm market leverage on long time-series data.
} 
empirical studies of capital structure. There I also introduce my question of interest and the empirical methodology for answering it. The data section follows and section 4 presents the results. Finally, I conclude in section 5 .

\section{Determinants of leverage and methodology}

As Myers (2003) notes, the present theories of capital structure are conditional. They are relevant in different settings. This is well documented in empirical studies of capital structure, which have found support for all theories. Firm behavior seems to be a hybrid of the proposed theoretical foundations. ${ }^{4}$

In a recent study, Frank and Goyal (2004) use US publicly traded firms over 19502000 and evaluate the importance of 36 factors (both firm- and economy-specific) on leverage. ${ }^{5}$ They conclude that seven factors - median industry leverage, market-to-book ratio, collateral, profits, dividend paying, logarithm of assets, and expected inflationare the most reliable ones.

The present empirical evidence on capital structure is that profitability as well as market-to-book ratio and dividend paying are negatively related to leverage. More profitable firms have larger internal slack and therefore a smaller need for external finance. Market-to-book ratio proxies growth opportunities and are negatively related to leverage due to the agency costs between the owners and bondholders. Dividend-paying firms are considered to be financially unconstrained, and unconstrained firms are expected to be less dependent on debt. Median industry leverage, collateral, log of assets, and expected

\footnotetext{
${ }^{4}$ Beside Myers (2003), see Harris and Raviv (1991) for a detailed review of theoretical and empirical capital structure studies.

${ }^{5}$ Frank and Goyal (2004) use Compustat data.
} 
inflation are found to be positively related with leverage. It is natural to think that firms with more assets and more collateral available face less obstacles in receiving debt, and, hence, have higher leverage. The expectation of high inflation makes credit cheaper today and therefore is positively related to leverage. Industry leverage is important since firms in the same industry are exposed to the same technology and therefore are likely to have a similar optimal financial structure. ${ }^{6}$

In contrast with Frank and Goyal (2004), Korajczyk and Levy (2003) find that the domestic macroeconomic conditions, ${ }^{7}$ besides inflation, help determine a firm's leverage. They show that financially unconstrained firms take into account the macroeconomic situation when issuing debt or equity more than constrained firms, whose issue choice follows less the macro movements in the country.

Few papers have taken the challenge to pool firm data from different countries and shed light upon the effects of country differences on firm leverage. While controlling for macroeconomic factors, Demirgüç-Kunt and Maksimovic (1995) and Schmukler and Vesperoni (2001) try to pin down the importance of institutional factors. Demirgüç-Kunt and Maksimovic (1995) study the relation of firm financial structure to the local capital market development. They aggregate firm level data to country averages. Their sample consisted of 31 developed and developing countries in 1981-91. They find a statistically

\footnotetext{
${ }^{6}$ MacKay and Phillips (2003) show that not only industry dummies but also firm position in its industry matters (e.g. proximity to median industry capital/labor ratio). Frank and Goyal (2004) show that omitting industry from the leverage regression turns many other firm characteristics significant. Hence, apparently industry captures a number of different effects.

${ }^{7}$ They use three macroeconomic variables - 2-year aggregate domestic non-financial corporations profit growth and 2-year equity market returns and commercial paper spreads - to describe overall tendencies in the market.
} 
significant negative relation between the stock market development and the debt/equity ratio. They also observe a positive relationship between the local banking sector size and leverage.

Schmukler and Vesperoni (2001) are interested in the effect of a country's financial liberalization on firm capital structure. Their analysis is based on seven developing countries from Asia and South America in the 1980's and 1990's. Interestingly, they find that after financial liberalization (after achieving access to international debt and equity markets), the debt-to-equity ratios did not change, but the share of short-term debt increased. So financial liberalization alters debt structure but not the debt/equity ratio.

The cross-country studies cited above show that some institutional factors are assessable and significant determinants of firm leverage even after controlling for macroeconomic variables. $^{8}$ In my research, I focus on the significance of country factors in leverage estimation and whether the effects of those factors are the same across firm types. Considering that previous research on the topic has been done on relatively large companies my study will shed light on small firm capital structure as well.

An important issue for empirical studies and their comparability is the precise definition of leverage used. Rajan and Zingales (1995) offer six different definitions of leverage. ${ }^{9}$ Due to data limitations, I use two of them. First, the broadest definition of leverage - ratio of total liabilities to total assets - does not differentiate between the

\footnotetext{
${ }^{8}$ Frank and Goyal (2004) use only US data and therefore only observe the time variation of country variables while not observing the cross-sectional variation.

${ }^{9}$ Rajan and Zingales (1995) divide the leverage measures into two groups. First, measures that evaluate the share of debt to assets, where the definitions debt and assets vary. The debt can be measured as broadly as total liabilities. Second, measures that evaluate interest coverage.
} 
different sources of debt (accounts payable, bank debt, or bonds). Second, the narrow definition of leverage is the ratio of total debt (short- plus long-term credit) to debt plus shareholders funds. From now on I call the first measure as "broad leverage" or "Leverage 1" and the second measure as "narrow leverage" or "Leverage 2". I use only book leverage in my analysis because for unlisted firms the market ratio does not exist. ${ }^{10}$ Narrow leverage corresponds to the leverage Rajan and Zingales (1995) use in their empirical analysis.

I contrast the importance of firm characteristics with country characteristics in determining the firm leverage ratio. I ask whether country effects have the same influence on all types of firms in a country. Is listed firm leverage determined by the same factors as that of unlisted firms? Do firms of different size have the same leverage determinants?

In answering these questions, I use two approaches. First, I perform an Analysis of Variance (ANOVA) of leverage for detecting the importance of the size, industry, and country factors in leverage variation. Second, I use regression analyses for comparing my study to previous research in the field.

The ANOVA exercise explains how much of the variation of the variable of interest is explained by different sets of variables. I use four sets of explanatory variables - size,

\footnotetext{
${ }^{10}$ For listed firms I computed both book and market leverage ratios. I estimated exactly the same leverage specification as Rajan and Zingales (1995). I received similar estimates (the results of those estimates are available upon request). Hence, I conclude that my data quality is comparable to the data used in the existing capital structure studies.
} 
industry, country, and year. ${ }^{11}$ I categorize firms into five size classes ${ }^{12}$ and use the 3 -digit NACE industry classification (I have 51 industries).

Besides analysing how many different types of factors explain the leverage variation, I run a simple leverage regression to observe the direction of the effects. The basic form of the regression is the following:

$$
Y_{i j t}=\alpha+\beta_{j}+\gamma_{t}+\delta X_{i j t}+\varepsilon_{i j t},
$$

where $i$ is the index of firm, $j$ is the index of country, and $t$ is the index of year. $X_{i j t}$ contains the firm-specific variables profitability, tangibility, logarithm of assets, and median industry leverage. $\beta_{j}$ is the country fixed effect and $\gamma_{t}$ is the year effect. $\varepsilon_{i j}$ is the random disturbance. In the next step, I am also interested in determining the country factors that matter to a firm's capital structure. Therefore, I add countryspecific variables to the regression:

$$
Y_{i j t}=\alpha+\beta_{j}+\gamma_{t}+\delta X_{i j t}+\zeta C_{j t}+\varepsilon_{i j t}
$$

where $C_{j t}$ are the country variables. Many different country characteristics have been proposed by earlier studies. Since some of those variables are strongly correlated with each other, I selected five measures to pin down the country effect. From macro factors I include GDP growth and inflation as Demirgüç-Kunt and Maksimovic (1995)

\footnotetext{
${ }^{11}$ The ANOVA estimation finds the total sum of squares of the dependent variable (SST), which is decomposed to the sum of squares of the model (SSR) and the sum of squares of the error term (SSE). Note that the ratio SSR/SST is the $R^{2}$ in the OLS regression. Also, ANOVA calculates for each explanatory variable the partial sum of squares.

${ }^{12}$ Class 1 firms have total assets smaller than $\$ 1$ million. Class 2 firms have total assets between $\$ 1$ and 2 million. Class 3 firms have total assets between $\$ 2$ and 5 million. Class 4 firms have total assets between $\$ 5$ to 50 million and finally, Class 5 firms have total assets above $\$ 50$ million. The median number of employees in each size group is $10,15,22,55$ and 391 , respectively.
} 
did. GDP growth rate proxies the firms' growth opportunities. Since high-growth firms are expected to rely more on internal funds, the correlation of this variable with leverage is expected to be negative. The correlation of inflation and leverage is expected to be positive. As Holmstrom and Tirole (1997) note, it is important to consider the capital constraints of financial intermediaries. Total domestic savings to GDP proxies the capital supply of the domestic financial sector. A higher savings ratio should cause higher leverage levels. From institutional factors, I add statutory corporate tax rate (including local taxes) and total market capitalization to GDP. Higher taxes should cause higher leverage while higher stock market development is expected to lead to lower levels of leverage.

\section{Data}

I use firm-level data from the Amadeus (Analyse MAjor Databases from EUropean Sources) database, collected by Bureau Van Dijk. The company accounting statements are harmonized by Bureau Van Dijk making the cross-country comparisons reliable. Data are also available for unlisted firms. Due to national legislations, the coverage of financial variables varies across countries. This limits the number of countries included in the analysis ${ }^{13}$ and affects my choice of variables.

The firms selected are the Amadeus Top 1 million companies (online version in February and March 2004). Those firms had to meet at least one of the following criteria to be included in Amadeus: operating revenue greater than 1 million euros, total assets greater than 2 million euros, and number of employees greater than 10. For firms from the United Kingdom, Germany, France, and Italy these cut offs were 1.5, 3 and 15,

\footnotetext{
${ }^{13}$ Amadeus data cover firms from 37 European countries.
} 
respectively. The European Commission defines the firms with less than 10 employees as micro-enterprises. Hence, the Amadeus inclusion criteria bias the sample only against the smallest firms but provide an excellent possibility to analyse the behavior of small and medium-sized firms.

I exclude a firm if: total assets were not given or were negative; the sum of detail balance sheet items deviated more than $5 \%$ from total assets given; shareholders funds, current liabilities or non-current liabilities were not given; industry was missing; it was from the financial intermediation sector ${ }^{14}$ or the leverage ratio was positioned more than three times the difference between the 25 th and 75 th percentile away (eliminating outliers).

My study is based on firms from 10 Western European countries. I compare the coverage of the final sample I use with data from "Enterprises in Europe" provided by the European Commission and Eurostat. These data cover the number of firms, employment and production of firms from the European Union and the European Free Trade Agreement countries. "Enterprises in Europe" is expected to cover the whole population of firms in the country. ${ }^{15}$ I assess the representativeness of Amadeus data across firm size and industry. For comparison I divide firms into three size and six industry classes. ${ }^{16}$

Table 1 in the appendix presents the correlations of firm size distributions across

\footnotetext{
${ }^{14}$ The financial intermediation sector has a specific balance sheet structure. It is standard to disregard these firms in capital structure studies.

${ }^{15}$ For more details about "Enterprises in Europe" see Kumar, Rajan, and Zingales (2002).

${ }^{16}$ Note that firms are divided into size classes based on the number of employees. Only two-thirds of firms in my data report employment. Therefore, the coverage figures presented should be taken as proxies for the coverage of a full sample.
} 
industries and industry distributions correlations for each country. Amadeus data are well representative for most of the countries, except Germany and Switzerland. From Germany a small number of mainly large firms are covered by my data. ${ }^{17}$ The industry representativeness of Amadeus is good on average. Manufacturing firms are over-sampled from all countries, while services, trade, and construction are under-represented in some countries. $^{18}$

The number of firms reaches 482,783 in 2000 in my sample. This is an order of magnitude more than in any present cross-country capital structure study of which I am aware. The existing cross-country studies use mainly the Global Vantage database (Rajan and Zingales (1995) and Demirgüç-Kunt and Maksimovic (1995)) or International Finance Corporations (IFC) data ((Booth, Aivazian, Demirgüç-Kunt, and Maksimovic 2001, Schmukler and Vesperoni 2001)). In Rajan and Zingales's (1995) study of seven developed countries the largest sample of firms is from the US (2583 firms) and the smallest from Italy (118 firms). In Booth, Aivazian, Demirgüç-Kunt, and Maksimovic (2001) the number of firms from each country remains below one hundred. The average firm size in those databases is much larger than in my sample. Therefore, my study gives a better understanding of the average firm leverage.

Table 1 presents the balance sheet structure of the firms in my sample in the year

${ }^{17}$ Small and medium sized German firms are not legally forced to disclose (Desai, Gompers, and Lerner 2003).

${ }^{18}$ The representativeness of Amadeus data is also presented in Gomez-Salvador, Messina, and Vallanti (2004). They find that firms in the Amadeus data cover on average $25 \%$ of the employment in National Labor Force Surveys. Different industries are well represented in Amadeus data. Gomez-Salvador, Messina, and Vallanti (2004) conclude that the industry coverage is similar across countries and stable over time. 
2000. Panel A has information about listed firms. The first four columns are comparable to Rajan and Zingales's (1995) Table 2. French and Italian firms' share of long-term debt is much lower in my sample. More than half of the firms from those countries do not report any long-term debt. My sample of firms is larger than Rajan and Zingales and it is likely that their sample covered a larger fraction of firms with long-term debt. ${ }^{19}$ An interesting finding from comparing listed (Panel A) and unlisted (Panel B) firms is that the fraction of current liabilities is much larger for unlisted firms while the share of non-current liabilities as well as shareholders funds is larger for listed firms.

Table 2 presents mean and median leverage ratios across countries, stock-market listed and unlisted firms and two different leverage measures in 2000. Both leverage measures are higher for unlisted firms. ${ }^{20}$ This confirms the finding of Table 1 that shareholders funds are a more common source of finance for listed firms. Broad leverage is higher than narrow leverage and its level varies less across countries. Median broad leverage varies from $86 \%$ in Italy to $67 \%$ in Finland among unlisted firms and from $64 \%$ in Portugal to 50\% in the United Kingdom (means are slightly lower) among listed firms. Median narrow leverage varies from $51 \%$ in Portugal to $0 \%$ in Italy among unlisted firms and from $51 \%$ in Portugal to $15 \%$ in Sweden among listed firms. The large difference between leverage measures in Italy documents that most of the Italian firms' financing comes from short-term non-debt financial sources.

I also make use of country-specific variables. Macro data (inflation, GDP growth ratio, and saving ratio) and capital market size info (total market capitalization to GDP) are from the World Bank, World Development Indicators. The statutory corporate

\footnotetext{
${ }^{19}$ See also a discussion about French and Italian firms balance sheet structure in Giannetti (2003, page 190-191) who used the Amadeus sample as well.

${ }^{20}$ Except for the narrow leverage in France. French unlisted firms use very little debt finance.
} 
income tax rate is adopted from Devereux, Griffith, and Klemm (2002).

\section{Results}

\subsection{Analysis of Variance}

In this section, I explore how much different sources explain leverage variation. I use pooled data - across firms from different countries and over eight years. Pooled data analysis is more powerful than simple cross-sectional data analysis since it allows the incorporation of both firm and country specific factors plus time invariant country effects.

Table 3 Panel A presents the ANOVA results for listed firm broad leverage. The largest share (about 50\%) of leverage variation is explained by industry dummies. Size dummies and country dummies explain $20 \%$ and $18 \%$, respectively. In the second column, I add firm profitability and tangibility. The results seem to be robust to the inclusion of the firm-specific variables and the model gains $2 \%$ in descriptive power. In the last column of Table 3, I include in addition to firm characteristics the country specific variables. The explanatory share of country dummies drops to $11 \%$. Hence, unobservable country characteristics explain only $11 \%$ of listed firm leverage variation. Table 3 Panel B presents the comparable ANOVA results for listed firm narrow leverage. Differently from broad leverage, the inclusion of firm specific characteristics decreases the explanatory power of size and industry dummies significantly while the inclusion of country specific variables does not decrease the explanatory share of country dummies.

Table 4 Panel A presents the corresponding results for unlisted companies broad leverage. Country dummies explain close to half while industry and size dummies explain approximately one-fourth and one-fifth of leverage variation, respectively. The inclusion 
of firm characteristics in the second column does not change the results. Hence, the well-known firm characteristics contribute little to the leverage determination. The inclusion of country variables in column 3 decreases the significance of country dummies by half. Still, a large $25 \%$ of leverage variation is explained by unobservable country institutional factors. Table 4 Panel B presents the comparable ANOVA results for unlisted firm narrow leverage. For this leverage definition the country dummies are even more prevalent. Size and industry of the firm explain a minor share of leverage variation.

An interesting finding from comparing listed and unlisted firms is that while industry effects explain approximately 2.5 times more than country effects for listed firms, for unlisted firms the pattern is reversed - country effects explain roughly two times more than industry effects (for the narrow definition of leverage even five times more). Hence, it seems that the country of incorporation bears more valuable information for the unlisted firms. Both observable and unobservable country factors explain the larger share of leverage variation of unlisted firms.

One explanation for the different influence of country factors for listed and unlisted firms is that listed firms have better financing opportunities. Being listed on the stock market can be considered as a signal of good quality and therefore the potential financing sources for those firms are not limited to domestic financiers. Claessens, Klingebiel, and Schmukler (2004) report that for high-income countries the market capitalization of international firms (firms that cross-list abroad) to total market capitalization is $56 \%$ in 2000. This explains why listed firm leverage variation is less explained by country factors compared to unlisted firms. Hence, for listed firms the industry technology carries the most important part of leverage determination. Unlisted companies on the other hand rely mainly on finance from the domestic market. Therefore, the country factors matter 
a lot in explaining leverage variation.

Note that the adjusted $R^{2}$ 's are quite low. In a comparable study Booth, Aivazian, Demirgüç-Kunt, and Maksimovic (2001) received a $R^{2}$ above $40 \%$. On the other hand, Schmukler and Vesperoni (2001) reported a $R^{2}$ as low as $4-12 \%$. An open question is to what extent low explanatory power of the existing empirical studies correspond to the measurement error in leverage ratios or alternatively to the lack of dynamic modelling. ${ }^{21}$

Since the stock market listed firms are on average much larger than the unlisted firms, it is interesting to see how the firms from different size groups respond to industry and country effects. In Table 5 Panel A the results are presented for listed firm broad leverage. ${ }^{22}$ Firms from the three smallest size groups are combined since the number of observations in each class separately were small. The industry dummies explain a larger share of leverage variation compared to country effects in all size classes. The same holds for narrow leverage (Table 5 Panel B).

Table 6 presents the results for unlisted firms. Up to the fourth size class of the firms, country factors explain the biggest share of broad leverage variation (Panel A). The industry and country characteristics explain roughly the same share of leverage variation for firms in the fourth size group. The largest firms face a reversed pattern-industry effects largely dominate the country effects. In other words, we observe the dilution of country effects on firm leverage when firms become larger. The largest unlisted firms share a common feature with listed firms - industry effects dominate country effects. Hence, it is important to distinguish the size of the firm besides the traded/nontraded firm distinction. It appears that being listed does not affect the sources of capital struc-

\footnotetext{
${ }^{21}$ See Strebulaev (2003) for details about dynamic capital structure.

${ }^{22}$ Firm and country variables are not introduced here since they do not change the pattern of results.
} 
ture for large firms. This might be since large firms are more likely to go public (Pagano, Panetta, and Zingales 1998) as well as more likely to issue equity in international markets (Claessens, Klingebiel, and Schmukler 2003). Interestingly for the narrow leverage definition (Table 6 Panel B) we observe the same pattern for all size classes - country factors remain as the most important factor for all firms irrespective of size. Table 7 shows the liability structure across size groups. Current liabilities are far more important for the smallest firms (Size 1). The liability structure of the largest firms (Size 5) resembles most the liability structure of listed firms in Table 2. The different results found in ANOVA on size groups of firms while using different leverage measures call for attention.

The analysis in this section shows that both firm and country specific variables are important for explaining leverage variation. The relative importance of those factors varies by firm type. Small and unlisted firms are affected more by country characteristics irrespective of the leverage measure used. Half of the country explanatory power emerges from unobservable institutional factors for unlisted firms. Therefore, it is important to consider a firm's country of incorporation in a study of leverage even after controlling for observable country factors.

\subsection{Regression Analysis}

As in the ANOVA analysis I use pooled data in the regression analysis. I compare the results of this section with findings from earlier studies on capital structure. Table 8 reports the results. All regressions include country and year dummies, which are jointly statistically significant in all specifications.

Panel A of Table 8 reports the leverage regression results for listed firms. Column 1 
and 2 report the results for the broad leverage measure and column 3 and 4 for narrow leverage. All regressions include country and year dummies. In the 1st and 3rd column, no country specific time-varying variables are included into the leverage estimation. All firm specific factors are statistically significant in all specifications. $\operatorname{Size}^{23}$ and tangibility are positively related to leverage. Profitability is negatively related to leverage. The signs coincide with the findings of earlier capital structure studies on firms from developed countries (Rajan and Zingales 1995). In the 2nd and 4th columns, I add the set of country time-varying variables. The goodness of fit almost does not change. As in ANOVA, the inclusion of country-specific variables absorbs some part of the explanatory power of country dummies. Only two out of five country variables are statistically significant for broad leverage regression and three for narrow leverage regression. The higher savings ratio to GDP and lower stock market capitalization are related to higher leverage. Still note that, the coefficients for country specific variables are very small.

Panel B of Table 8 presents the results for unlisted firms. The coefficients on all firm characteristics in all specifications are statistically significant. For the narrow leverage measure (column 3 and 4) the coefficients have the same signs as for listed companies but the signs are negative for tangibility and size for the broad leverage regressions. Larger firms as well as firms with a higher share of tangible assets have lower broad leverage. Booth, Aivazian, Demirgüç-Kunt, and Maksimovic (2001) also found a negative coefficient on tangibility in their sample of firms from developing countries. They define leverage as total liabilities over total liabilities plus net worth, which corresponds to my broad leverage definition. It is well known for transition countries to have a negative

\footnotetext{
${ }^{23}$ All regression results are robust if, instead of logarithm of total assets, the discrete size variable - the five size groups exploited in the ANOVA section-is used.
} 
coefficient for tangibility (Cornelli, Portes, and Schaffer 1998). Cornelli, Portes, and Schaffer's result was robust for two leverage definitions - total debt to total assets and total bank debt to total assets. Therefore, the negative coefficient in front of tangibility in my broad leverage regression of unlisted firms from Western European countries is consistent with results from less developed countries. The negative sign in front of size is puzzling. ${ }^{24}$ One explanation for the negative relation between size and leverage may be that size proxies the firm growth opportunity, which is expected to be negatively related to leverage. This is supported by Evans's (1987) finding that small firms are growing more quickly.

Five out of four country variables in unlisted firm leverage regressions have highly statistically significant coefficients for both leverage measures. As in the case of listed firms the coefficients have very low values. The negative signs of the GDP growth in both leverage measure regressions contradict theoretical predictions as well as negative coefficients on inflation and savings rate in broad leverage regression.

The main difference between the two leverage measures used in my analysis is the inclusion of trade credit and other non-debt current liabilities in the broad leverage measure. As was shown in the section on the ANOVA analysis, unlisted firms (see Table 1) and small firms (see Table 7) have on average a larger share of current liabilities. This may be considered as a potential explanation of negative signs in front of tangibility and the log size in the broad leverage regressions. To see whether the larger share of current liabilities explains those negative signs I run the broad leverage measure regression across size groups. Table 9 presents the results. In Panel A for listed firm regressions we see

\footnotetext{
${ }^{24}$ In fact, Rajan and Zingales (1995) found a negative significant coefficient in front of size for German listed firms.
} 
that the signs are really different for the smallest firms - tangibility as well as size enter with a negative coefficients. From Panel B for unlisted firms we see that the signs in front of tangibility and the logarithm of size change across size groups but we can not conclude that the signs are negative for smaller firms and positive for larger firms. Therefore, the larger proportion of current liabilities does not explain the flipped signs in the broad leverage regression.

I run the regressions also on cross-sectional data to see whether the results are stable over time and over countries. I find firm-specific factors to have stable coefficients over time for both leverage measures. The coefficients in front of country-specific timevarying variables change signs and significance over the years. This might be explained by the lack of variation in economy-wide variables across countries due to the similarity of countries in my study. I observe different signs on estimated coefficients in front of firm-specific variables in some country regressions compared to pooled regression. ${ }^{25}$

\section{Conclusions}

I use a large European firm data set to study the sources of leverage variation and provide the first available evidence on capital structure determinants for small firms. The importance of firm versus country factors in driving firm capital structure varies across firm types. Country-specific factors are most important for small and unlisted firms, suggesting that these firms, which are likely to operate under borrowing constraints, face non-firm-specific determinants of leverage. Specifically, I control for five country-specific time-varying macroeconomic variables while capturing the effects of time-invariant unmeasured country factors (such as institutions) using a set of dummy

\footnotetext{
${ }^{25}$ More specific results of year-specific and country-specific regressions are available on request.
} 
variables. I find that the share of leverage variation related to country-specific unobservable factors for listed and unlisted firms is approximately 10 and 25 percent, respectively. This is an important finding for at least two reasons: First, apparently a change in domestic macroeconomic variables and/or financial institutions can change a firms financial structure. Second, research in the field of capital structure should turn more attention on investigation of country-of-incorporation factors.

I use two leverage measures in my analysis and I find that the results are robust to the measure used for the listed firms but not for unlisted firms. The main difference between the two measures is that the broad one includes trade credit and other current liabilities. My findings based on listed firms are in accord with the existing theory and empirics of firm capital structure in that I find a positive relationship between firm size and leverage as well as between tangibility and leverage. The results for unlisted firms, however, are similar to the typical findings in the literature only when based on the narrow leverage measure (debt over debt plus shareholders funds). In contrast, when I use the broad leverage measure (total liabilities over total assets), the regression analysis results in a negative leverage effect of total assets and of the share of tangible assets to total assets. The puzzling new evidence reported here for firm types that have so far escaped investigation motivates future research in this area. 


\section{References}

Booth, Laurence, Varouj Aivazian, Asli Demirgüç-Kunt, and Vojislav Maksimovic, 2001, Capital structure in developing countries, Journal of Finance 56, 87-130.

Bradley, Michael, Gregg A. Jarrell, and E. Han Kim, 1984, On the existence of an optimal capital structure: Theory and evidence, Journal of Finance 39, 857-880.

Cambell, John Y., Martin Lettau, Burton G. Malkiel, and Yexiao Xu, 2001, Have individual stocks become more volatile? An empirical exploration of idiosyncratic risk, Journal of Finance 56, 1-43.

Carpenter, Robert E., and Bruce C. Petersen, 2002, Is the growth of small firms constrained by internal finance, Review of Economics and Statistics 84, 298-309.

Claessens, Stijn, Daniela Klingebiel, and Sregio L. Schmukler, 2003, Accessing international equity markets: What firms from which countries go abroad?, unpublished.

— , 2004, Stock market development and internationalization: Do economic fundamentals spur both similarly?, unpublished.

Cornelli, Francesca, Richard Portes, and Mark E. Schaffer, 1998, Financial structure of firms in the CEECs, in Olivier Bouin, Fabrizio Coricelli, and Françoise Lemoine, ed.: Different Paths to a Market Economy: China and European Economies in Transition . chap. 7 (CEPR/CEPII/OECD).

Demirgüç-Kunt, Asli, and Vojislav Maksimovic, 1995, Stock market development and firm financing choices, WB working paper 1461. 
Desai, Mihir, Paul Gompers, and Josh Lerner, 2003, Institutions, capital constraints and entrepreneurial firm dynamics: Evidence from Europe, NBER Working Paper.

Desai, Mihir A., C. Fritz Foley, and James R. Hines, 2004, A multinational perspective on capital structure choice and international capital markets, Journal of Finance 59, $2451-2487$.

Devereux, Michael P., Rachel Griffith, and Alexander Klemm, 2002, Corporate income tax reforms and international tax competition, Economic Policy 35, 451-495.

European Commission, and Eurostat, 2001, Enterprises in Europe 6 edn.

Evans, David S., 1987, Tests of alternative theories of firms growth, Journal of Political Economy 95, 657-674.

Frank, Murray Z., and Vidhan K. Goyal, 2004, Capital structure decisions: Which factors are reliably important?, unpublished.

Giannetti, Mariassunta, 2003, Do better institutions mitigate agency problems? evidence from corporate finance choices, Journal of Financial and Quantitative Analysis $38,185-212$.

Gomez-Salvador, Ramon, Julian Messina, and Giovanna Vallanti, 2004, Gross job flows and institutions in Europe, Labour Economics 11, 469-485.

Harris, Milton, and Artur Raviv, 1990, Capital structure and the informational role of debt, Journal of Finance 45, 321-349.

— , 1991, The theory of capital structure, Journal of Finance 46, 297-355. 
Holmstrom, Bengt, and Jean Tirole, 1997, Financial intermediation, loanable funds, and the real sector, Quarterly Journal of Economics 112, 663-691.

Jensen, Michael C., and William H. Meckling, 1976, Theory of the firm: Managerial behavior, agency costs and ownership structure, Journal of Financial Economics 3, 305-360.

Korajczyk, Robert A., and Amnon Levy, 2003, Capital structure choice: Macroeconomic conditions and financial constraints, Journal of Financial Economics 68, 75.

Kumar, Krishna B., Raghuram G. Rajan, and Luigi Zingales, 2002, What determines firm size?, NBER working paper 7208.

Levy, Amnon, 2001, Why does capital structure choice vary with macroeconomic conditions?, Haas School of Business Working Paper.

MacKay, Peter, and Gordon W. Phillips, 2003, How does industry affect firm financial structure?, Forthcoming in Review of Financial Studies.

Modigliani, F., and M. Miller, 1963, Corporate income taxes and the cost of capital: a correction, The American Economic Review 53, 433-443.

Morck, Randall, Bernard Yeung, and Wayne Yu, 2000, The information content of stock markets: Why do emerging markets have synchronous stock price movements?, Journal of Finanial Economics 58, 215-260.

Myers, Stewart C., 1977, Determinants of corporate borrowing, Journal of Financial Economics 5, 147-175.

— 2003, Financing of corporations, in Handbook of the Economics of Finance . pp. 215-247 (Elsevier North Holland). 
Pagano, Marco, Fabio Panetta, and Luigi Zingales, 1998, Why do companies go public? An empirical analysis, Journal of Finance 53, 27-64.

Rajan, Raghuram, and Luigi Zingales, 1995, What do we know about capital structure? Some evidence from international data, Journal of Finance 50, 1421-1460.

Schmukler, Sergio, and Esteban Vesperoni, 2001, Firms' financing choices in bank-based and market-based economies, in Asli Demirgüç-Kunt, and Ross Levine, ed.: Financial Structure and economic growth: A cross-country comparison of banks, markets, and development . chap. 9, pp. 347-375 (MIT Press).

Strebulaev, Ilya A., 2003, Do tests of capital structure theory mean what they say?, unpublished.

Titman, Sheridan, and Roberto Wessel, 1988, The determinants of capital structure, Journal of Finance 43, 1-19. 


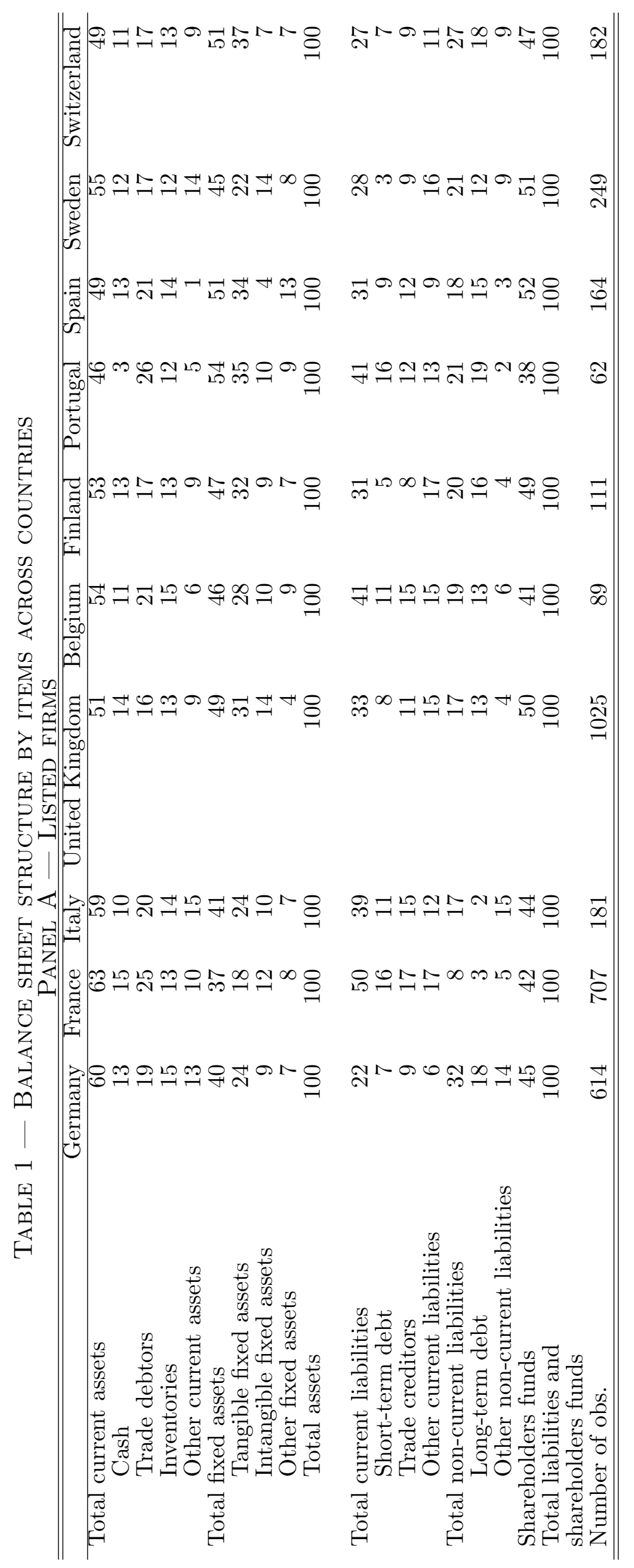




\begin{tabular}{|c|c|c|c|c|c|}
\hline \multirow[t]{2}{*}{ Country } & \multirow{2}{*}{ 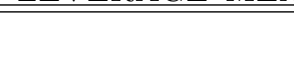 } & \multicolumn{2}{|c|}{$\begin{array}{l}\text { Listed firms } \\
\end{array}$} & \multicolumn{2}{|c|}{ "Unlisted firms } \\
\hline & & Leverage1 & Leverage2 & Leverage1 & Leverage2 \\
\hline \multirow[t]{4}{*}{ Belgium } & Mean & .59 & .36 & .72 & .46 \\
\hline & Median & .58 & .34 & .76 & .45 \\
\hline & St. Dev. & .23 & .27 & .24 & .36 \\
\hline & Number of firms & 84 & 84 & 28194 & 28194 \\
\hline \multirow{4}{*}{ Finland } & Mean & .51 & .29 & .65 & .39 \\
\hline & Median & .54 & .28 & .67 & .34 \\
\hline & St. Dev. & .16 & .20 & .23 & .32 \\
\hline & Number of firms & 111 & 111 & 9549 & 9549 \\
\hline \multirow[t]{4}{*}{ France } & Mean & .57 & .30 & .71 & .23 \\
\hline & Median & .60 & .28 & .74 & .12 \\
\hline & St. Dev. & .22 & .24 & .25 & .32 \\
\hline & Number of firms & 703 & 703 & 136868 & 136868 \\
\hline \multirow{4}{*}{ Germany } & Mean & .54 & .36 & .73 & .40 \\
\hline & Median & .57 & .33 & .77 & .35 \\
\hline & St. Dev. & .25 & .28 & .24 & .38 \\
\hline & Number of firms & 558 & 558 & 6637 & 6637 \\
\hline \multirow{4}{*}{ Italy } & Mean & .57 & .26 & .81 & .23 \\
\hline & Median & .59 & .20 & .86 & .00 \\
\hline & St. Dev. & .21 & .23 & .18 & .33 \\
\hline & Number of firms & 127 & 127 & 86209 & 86209 \\
\hline \multirow{4}{*}{ Portugal } & Mean & .62 & .49 & .72 & .50 \\
\hline & Median & .64 & .51 & .74 & .51 \\
\hline & St. Dev. & .22 & .26 & .20 & .31 \\
\hline & Number of firms & 62 & 62 & 7830 & 7830 \\
\hline \multirow{4}{*}{ Spain } & Mean & .50 & .33 & .70 & .35 \\
\hline & Median & .55 & .36 & .75 & .28 \\
\hline & St. Dev. & .23 & .23 & .26 & .35 \\
\hline & Number of firms & 154 & 154 & 113711 & 113711 \\
\hline \multirow{4}{*}{ Sweden } & Mean & .53 & .23 & .72 & .38 \\
\hline & Median & .55 & .15 & .75 & .34 \\
\hline & St. Dev. & .20 & .24 & .22 & .36 \\
\hline & Number of firms & 229 & 229 & 31834 & 31834 \\
\hline \multirow{4}{*}{ Switzerland } & Mean & .53 & .34 & .64 & .43 \\
\hline & Median & .56 & .32 & .68 & .46 \\
\hline & St. Dev. & .18 & .20 & 0.24 & .32 \\
\hline & Number of firms & 181 & 181 & 349 & 349 \\
\hline \multirow{4}{*}{ United Kingdom } & Mean & .49 & .29 & .69 & .46 \\
\hline & Median & .50 & .26 & .70 & .42 \\
\hline & St. Dev. & .23 & .25 & .28 & .40 \\
\hline & Number of firms & 1010 & 1010 & 58383 & 58383 \\
\hline
\end{tabular}

NOTES: Leverage1 is defined as total liabilities over total assets. Leverage2 is defined as debt over debt plus equity. 
TABle 3 - ANOVA RESUlts fOR Listed Firms

\begin{tabular}{|c|c|c|c|c|c|c|}
\hline Source & \multicolumn{4}{|c|}{ PANEL A - BROAD LEVERAGE } & "SSR & \\
\hline \multirow[t]{2}{*}{ Size } & 20 & $20 \%$ & 19 & $18 \%$ & 20 & $17 \%$ \\
\hline & ( 5 ) & & ( 5 ) & & ( 5 ) & \\
\hline \multirow[t]{2}{*}{ Industry } & 46 & $47 \%$ & 51 & $46 \%$ & 51 & $44 \%$ \\
\hline & ( 48 ) & & ( 48 ) & & ( 48 ) & \\
\hline \multirow[t]{2}{*}{ Country } & 17 & $18 \%$ & 19 & $17 \%$ & 13 & $11 \%$ \\
\hline & ( 10$)$ & & ( 10 ) & & $(10)$ & \\
\hline \multirow[t]{2}{*}{ Year } & 4 & $4 \%$ & 4 & $4 \%$ & 1 & $1 \%$ \\
\hline & ( 8 ) & & ( 8 ) & & ( 8 ) & \\
\hline Model & 98 & & 111 & & 114 & \\
\hline Total & 1027 & & 1027 & & 1027 & \\
\hline Firms ch. & No & & Yes & & Yes & \\
\hline Country ch. & No & & No & & Yes & \\
\hline Adj. $R^{2}$ & 0.09 & & 0.11 & & 0.11 & \\
\hline Obs. & 20686 & & 20686 & & 20686 & \\
\hline
\end{tabular}

\begin{tabular}{lrrrrrr} 
& & & & \\
& PANEL B & NARROW LEVERAGE \\
\hline \hline Source & SSR & & SSR & & SSR & \\
\hline Size & 25 & $19 \%$ & 20 & $11 \%$ & 20 & $11 \%$ \\
Industry & $(5)$ & & $(5)$ & & $(5)$ & \\
& 58 & $44 \%$ & 46 & $26 \%$ & 47 & $25 \%$ \\
Country & $(48)$ & & $(48)$ & & $(48)$ & \\
& 24 & $18 \%$ & 24 & $13 \%$ & 26 & $14 \%$ \\
Year & $(10)$ & & $(10)$ & & $(10)$ & \\
& 2 & $2 \%$ & 2 & $1 \%$ & 1 & $1 \%$ \\
Model & $(8)$ & & $(8)$ & & $(8)$ & \\
Total & 131 & & 180 & & 185 & \\
\hline Firms ch. & 1395 & & 1395 & & 1395 & \\
Country ch. & No & & Yes & & Yes & \\
Adj. $R^{2}$ & 0.09 & & No & & Yes & \\
Obs. & 20686 & & 0.13 & & 0.13 & \\
\hline \hline
\end{tabular}

NOTES: Numbers in cells refer to the partial sum of squares (SSR). The numbers in parentheses refer to the number of indicators. Broad leverage is defined as total liabilities to total assets. Narrow leverage is defined as debt to debt plus shareholders funds. Industry is 3-digit NACE. Firm size classes: Class 1 total assets smaller than $\$ 1$ million, Class 2 total assets between $\$ 1$ and 2 million, Class 3 total assets between $\$ 2$ and 5 million, Class 4 total assets between $\$ 5$ to 50 million, and Class 5 total assets above $\$ 50$ million. Firm characteristics are tangible assets to total assets and profit to assets ratios. Country characteristics are GDP growth rate, inflation, savings to GDP, statutory corporate income tax rate, and total market capitalization to GDP. 
TABle 4 - ANOVA RESUlts FOR UNLISTED FIRMS

PANEL A - BROAD LEVERAGE

\begin{tabular}{lrlrrrr}
\multicolumn{1}{c}{ PANEL A } & SSR & SSR & SSR & \\
\hline \hline Source & 2508 & $21 \%$ & 2448 & $21 \%$ & 2434 & $20 \%$ \\
& $(5)$ & & $(5)$ & & $(5)$ & \\
Industry & 2876 & $24 \%$ & 2708 & $23 \%$ & 2709 & $23 \%$ \\
& $(51)$ & & $(51)$ & & $(51)$ & \\
Country & 6082 & $52 \%$ & 5990 & $50 \%$ & 2953 & $25 \%$ \\
& $(10)$ & & $(10)$ & & $(10)$ & \\
Year & 50 & $0 \%$ & 52 & $0 \%$ & 46 & $0 \%$ \\
& $(8)$ & & $(8)$ & $(8)$ & \\
Model & 11773 & & 11936 & & 11971 & \\
Total & 180232 & & 180232 & 180232 & \\
\hline Firms ch. & No & Yes & Yes & \\
Country ch. & No & & No & Yes & \\
Adj. $R^{2}$ & 0.07 & 0.07 & 0.07 & \\
Obs. & 3035109 & 3035109 & 3035109 & \\
\hline \hline
\end{tabular}

\begin{tabular}{|c|c|c|c|c|c|c|}
\hline Source & SSR & & SSR & & SSR & \\
\hline \multirow[t]{2}{*}{ Size } & 1746 & $5 \%$ & 1614 & $5 \%$ & 1612 & $5 \%$ \\
\hline & $(5)$ & & $(5)$ & & ( 5 ) & \\
\hline \multirow[t]{2}{*}{ Industry } & 4375 & $14 \%$ & 2969 & $8 \%$ & 2968 & $8 \%$ \\
\hline & ( 51$)$ & & ( 51$)$ & & ( 51$)$ & \\
\hline \multirow[t]{2}{*}{ Country } & 21611 & $68 \%$ & 16490 & $47 \%$ & 9262 & $26 \%$ \\
\hline & $(10)$ & & $(10)$ & & $(10)$ & \\
\hline \multirow[t]{2}{*}{ Year } & 222 & $1 \%$ & 187 & $1 \%$ & 137 & $0 \%$ \\
\hline & ( 8 ) & & ( 8 ) & & ( 8 ) & \\
\hline Model & 31992 & & 35160 & & 35229 & \\
\hline Total & 375965 & & 375965 & & 375965 & \\
\hline Firms ch. & No & & Yes & & Yes & \\
\hline Country ch. & No & & No & & Yes & \\
\hline Adj. $R^{2}$ & 0.09 & & 0.09 & & 0.09 & \\
\hline Obs. & 3035109 & & 3035109 & & 3035109 & \\
\hline
\end{tabular}

Notes: Numbers in cells refer to the partial sum of squares (SSR). The numbers in parentheses refer to the number of indicators. Broad leverage is defined as total liabilities to total assets. Narrow leverage is defined as debt to debt plus shareholders funds. Industry is 3-digit NACE. Firm size classes: Class 1 total assets smaller than $\$ 1$ million, Class 2 total assets between $\$ 1$ and 2 million, Class 3 total assets between $\$ 2$ and 5 million, Class 4 total assets between $\$ 5$ to 50 million, and Class 5 total assets above $\$ 50$ million. Firm characteristics are tangible assets to total assets and profit to assets ratios. Country characteristics are GDP growth rate, inflation, savings to GDP, statutory corporate income tax rate, and total market capitalization to GDP. 
TABle 5 - ANOVA Results FOR LISTED FIRMS

BY SIZE CLASSES

PANEL A - BROAD LEVERAGE

\begin{tabular}{|c|c|c|c|c|c|c|}
\hline$\overline{\text { Source }}$ & $\overline{\text { Size }<4}$ & & $\overline{\text { Size } 4}$ & & $\overline{\text { Size } 5}$ & \\
\hline \multirow[t]{2}{*}{ Industry } & 14 & $70 \%$ & 21 & $61 \%$ & 37 & $71 \%$ \\
\hline & (39) & & ( 46 ) & & (47) & \\
\hline \multirow[t]{2}{*}{ Country } & 4 & $21 \%$ & 8 & $24 \%$ & 13 & $24 \%$ \\
\hline & ( 10 ) & & $(10)$ & & ( 10 ) & \\
\hline \multirow[t]{2}{*}{ Year } & 1 & $3 \%$ & 4 & $11 \%$ & 1 & $2 \%$ \\
\hline & ( 8 ) & & ( 8 ) & & ( 8 ) & \\
\hline Model & 20 & & 35 & & 52 & \\
\hline Total & 91 & & 381 & & 529 & \\
\hline Adj. $R^{2}$ & 0.18 & & 0.08 & & 0.09 & \\
\hline Obs. & 1086 & & 6269 & & 13331 & \\
\hline
\end{tabular}

PANEL B - NARROW LEVERAGE

\begin{tabular}{lrrrrrr}
\hline \hline Source & Size $<4$ & & Size 4 & & Size 5 & \\
\hline Industry & 9 & $59 \%$ & 20 & $58 \%$ & 54 & $70 \%$ \\
& $(39)$ & & $(46)$ & & $(47)$ & \\
Country & 5 & $34 \%$ & 11 & $31 \%$ & 16 & $21 \%$ \\
& $(10)$ & & $(10)$ & & $(10)$ & \\
Year & 1 & $3 \%$ & 1 & $3 \%$ & 4 & $5 \%$ \\
& $(8)$ & & $(8)$ & & $(8)$ & \\
Model & 15 & & 35 & & 78 & \\
Total & 102 & & 458 & 792 & \\
\hline Adj. $R^{2}$ & 0.10 & & 0.07 & & 0.09 & \\
Obs. & 1086 & & 6269 & & 13331 & \\
\hline \hline NOT.Nan
\end{tabular}

$\overline{\text { Notes:Numbers in cells refer to the partial sum of squares }}$ (SSR). The numbers in parentheses refer to the number of indicators. Broad leverage is defined as total liabilities to total assets. Narrow leverage is defined as debt to debt plus shareholders funds. Industry is 3-digit NACE. Firm size classes: Class 1 total assets smaller than $\$ 1$ million, Class 2 total assets between $\$ 1$ and 2 million, Class 3 total assets between $\$ 2$ and 5 million, Class 4 total assets between $\$ 5$ to 50 million, and Class 5 total assets above $\$ 50$ million. 
TABle 6 - Anova Results For Unlisted Firms By SIZE Classes PANEL A - BROAD LEVERAGE

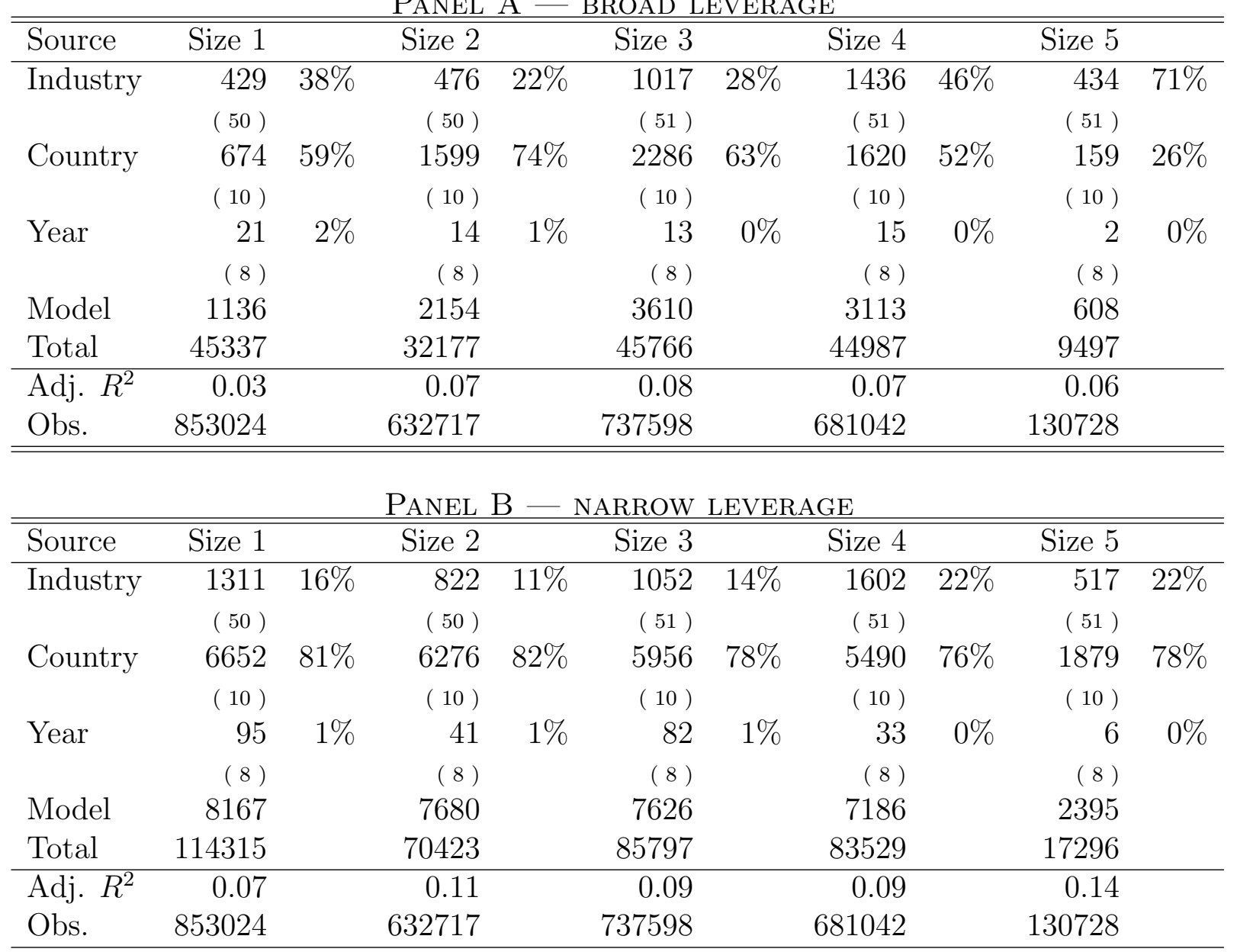

Notes:Numbers in cells refer to the partial sum of squares (SSR). The numbers in parentheses refer to the number of indicators. Broad leverage is defined as total liabilities to total assets. Narrow leverage is defined as debt to debt plus shareholders funds. Industry is 3-digit NACE. Firm size classes: Class 1 total assets smaller than $\$ 1$ million, Class 2 total assets between $\$ 1$ and 2 million, Class 3 total assets between $\$ 2$ and 5 million, Class 4 total assets between $\$ 5$ to 50 million, and Class 5 total assets above $\$ 50$ million. 
TABlE 7 - LIABILITIES STRUCTURE ACROSS COUNTRIES AND SIZE

\begin{tabular}{|c|c|c|c|c|c|}
\hline & & $\begin{array}{l}\text { Current } \\
\text { liabilities }\end{array}$ & $\begin{array}{r}\text { Non-current } \\
\text { liabilities }\end{array}$ & $\begin{array}{l}\text { Shareholders } \\
\text { funds }\end{array}$ & Number of firms \\
\hline Belgium & $\begin{array}{l}\text { Size } 1 \\
\text { Size } 2 \\
\text { Size } 3 \\
\text { Size } 4 \\
\text { Size } 5\end{array}$ & $\begin{array}{l}67 \\
51 \\
47 \\
50 \\
45\end{array}$ & $\begin{array}{l}22 \\
22 \\
23 \\
22 \\
23\end{array}$ & $\begin{array}{l}11 \\
27 \\
30 \\
28 \\
31\end{array}$ & $\begin{array}{l}7045 \\
6339 \\
8581 \\
6341 \\
1223\end{array}$ \\
\hline Finland & $\begin{array}{l}\text { Size } 1 \\
\text { Size } 2 \\
\text { Size } 3 \\
\text { Size } 4 \\
\text { Size } 5\end{array}$ & $\begin{array}{l}47 \\
40 \\
36 \\
32 \\
30\end{array}$ & $\begin{array}{l}23 \\
24 \\
29 \\
29 \\
31\end{array}$ & $\begin{array}{l}30 \\
35 \\
35 \\
39 \\
40\end{array}$ & $\begin{array}{r}4142 \\
1701 \\
1634 \\
1750 \\
505\end{array}$ \\
\hline France & $\begin{array}{l}\text { Size } 1 \\
\text { Size } 2 \\
\text { Size } 3 \\
\text { Size } 4 \\
\text { Size } 5\end{array}$ & $\begin{array}{l}93 \\
63 \\
58 \\
53 \\
46\end{array}$ & $\begin{array}{l}22 \\
10 \\
12 \\
15 \\
20\end{array}$ & $\begin{array}{r}-15 \\
27 \\
31 \\
31 \\
34\end{array}$ & $\begin{array}{r}49099 \\
32392 \\
29931 \\
24362 \\
4875\end{array}$ \\
\hline Germany & $\begin{array}{l}\text { Size } 1 \\
\text { Size } 2 \\
\text { Size } 3 \\
\text { Size } 4 \\
\text { Size } 5\end{array}$ & $\begin{array}{l}42 \\
43 \\
39 \\
36 \\
34\end{array}$ & $\begin{array}{l}39 \\
41 \\
39 \\
33 \\
34\end{array}$ & $\begin{array}{l}18 \\
16 \\
22 \\
30 \\
32\end{array}$ & $\begin{array}{r}640 \\
632 \\
1157 \\
3194 \\
2605\end{array}$ \\
\hline Italy & $\begin{array}{l}\text { Size } 1 \\
\text { Size } 2 \\
\text { Size } 3 \\
\text { Size } 4 \\
\text { Size } 5\end{array}$ & $\begin{array}{l}79 \\
74 \\
70 \\
63 \\
56\end{array}$ & $\begin{array}{l}10 \\
10 \\
11 \\
15 \\
18\end{array}$ & $\begin{array}{l}11 \\
16 \\
19 \\
22 \\
26\end{array}$ & $\begin{array}{r}16953 \\
25728 \\
31748 \\
27887 \\
3165\end{array}$ \\
\hline Portugal & $\begin{array}{l}\text { Size } 1 \\
\text { Size } 2 \\
\text { Size } 3 \\
\text { Size } 4 \\
\text { Size } 5\end{array}$ & $\begin{array}{l}57 \\
53 \\
51 \\
47 \\
41\end{array}$ & $\begin{array}{l}21 \\
22 \\
22 \\
22 \\
25\end{array}$ & $\begin{array}{l}22 \\
24 \\
27 \\
31 \\
34\end{array}$ & $\begin{array}{r}1408 \\
1690 \\
2189 \\
2261 \\
411\end{array}$ \\
\hline Spain & $\begin{array}{l}\text { Size } 1 \\
\text { Size } 2 \\
\text { Size } 3 \\
\text { Size } 4 \\
\text { Size } 5\end{array}$ & $\begin{array}{l}64 \\
53 \\
47 \\
46 \\
43\end{array}$ & $\begin{array}{l}15 \\
16 \\
18 \\
18 \\
20\end{array}$ & $\begin{array}{l}22 \\
30 \\
35 \\
36 \\
37\end{array}$ & $\begin{array}{r}54188 \\
28635 \\
27028 \\
19081 \\
2276\end{array}$ \\
\hline Sweden & $\begin{array}{l}\text { Size } 1 \\
\text { Size } 2 \\
\text { Size } 3 \\
\text { Size } 4 \\
\text { Size } 5\end{array}$ & $\begin{array}{l}50 \\
40 \\
33 \\
31 \\
30\end{array}$ & $\begin{array}{l}26 \\
30 \\
38 \\
39 \\
39\end{array}$ & $\begin{array}{l}25 \\
30 \\
29 \\
30 \\
31\end{array}$ & $\begin{array}{r}13097 \\
6525 \\
6758 \\
6554 \\
1639\end{array}$ \\
\hline Switzerland & $\begin{array}{l}\text { Size } 1 \\
\text { Size } 2 \\
\text { Size } 3 \\
\text { Size } 4 \\
\text { Size } 5\end{array}$ & $\begin{array}{l}43 \\
43 \\
30 \\
24 \\
26\end{array}$ & $\begin{array}{r}2 \\
16 \\
52 \\
36 \\
35\end{array}$ & $\begin{array}{l}55 \\
41 \\
19 \\
40 \\
39\end{array}$ & $\begin{array}{r}3 \\
4 \\
22 \\
181 \\
323\end{array}$ \\
\hline United Kingdom & $\begin{array}{l}\text { Size } 1 \\
\text { Size } 2 \\
\text { Size } 3 \\
\text { Size } 4 \\
\text { Size } 5\end{array}$ & $\begin{array}{l}81 \\
61 \\
48 \\
47 \\
41\end{array}$ & $\begin{array}{r}152 \\
21 \\
22 \\
24 \\
30\end{array}$ & $\begin{array}{r}-133 \\
18 \\
30 \\
29 \\
29\end{array}$ & $\begin{array}{r}5703 \\
6717 \\
19316 \\
23212 \\
7251\end{array}$ \\
\hline
\end{tabular}

Notes: Firm size classes: Class 1 total assets smaller than $\$ 1$ million, Class 2 total assets between $\$ 1$ and 2 million, Class 3 total assets between $\$ 2$ and 5 million, Class 4 total assets between $\$ 5$ to 50 million, and Class 5 total assets above $\$ 50$ million. The smallest firms in France and the UK had on average negative shareholders funds, which explains the bizzare figures. 
TABLE 8 - LEVERAGE REGRESSION IN 1995-2002 PANEL A - LISTED FIRMS

\begin{tabular}{|c|c|c|c|c|}
\hline \multirow[b]{2}{*}{ Const. } & \multicolumn{2}{|c|}{ Leverage 1} & \multicolumn{2}{|c|}{$\begin{array}{c}\text { Leverage } 2 \\
\end{array}$} \\
\hline & $\begin{array}{l}.005 \\
(.034)\end{array}$ & $\begin{array}{l}.413 \\
(.065)^{* * *}\end{array}$ & $\begin{array}{l}-.037 \\
(.033)\end{array}$ & $\begin{array}{c}-.002 \\
(.073)\end{array}$ \\
\hline Tangibility & $\begin{array}{l}.042 \\
(.014)^{* * *}\end{array}$ & $\begin{array}{c}.04 \\
(.014)^{* * *}\end{array}$ & $\begin{array}{c}.15 \\
(.016)^{* * *}\end{array}$ & $\begin{array}{l}.151 \\
(.016)^{* * *}\end{array}$ \\
\hline Profitability & $\begin{array}{l}-.095 \\
(.01)^{* * *}\end{array}$ & $\begin{array}{l}-.096 \\
(.01)^{* * *}\end{array}$ & $\begin{array}{c}-.119 \\
(.014)^{* * *}\end{array}$ & $\begin{array}{l}-.119 \\
(.014)^{* * *}\end{array}$ \\
\hline Log assets & $\begin{array}{c}.016 \\
(.002)^{* * *}\end{array}$ & $\begin{array}{c}.016 \\
(.002)^{* * *}\end{array}$ & $\begin{array}{c}.019 \\
(.002)^{* * *}\end{array}$ & $\begin{array}{l}.019 \\
(.002)^{* * *}\end{array}$ \\
\hline Industry leverage & $\begin{array}{l}.751 \\
(.043)^{* * *}\end{array}$ & $\begin{array}{c}.75 \\
(.043)^{* * *}\end{array}$ & $\begin{array}{l}.501 \\
(.035)^{* * *}\end{array}$ & $\begin{array}{l}.502 \\
(.035)^{* * *}\end{array}$ \\
\hline GDP growth & & $\begin{array}{c}-1.00 \mathrm{e}-05 \\
(.002)\end{array}$ & & $\begin{array}{l}.002 \\
(.003)\end{array}$ \\
\hline Inflation & & $\begin{array}{l}-.005 \\
(.002)^{* *}\end{array}$ & & $\begin{array}{c}-.001 \\
(.003)\end{array}$ \\
\hline Corporate tax & & $\begin{array}{c}-.00007 \\
(.0005)\end{array}$ & & $\begin{array}{c}-.004 \\
(.0007)^{* * *}\end{array}$ \\
\hline Savings & & $\begin{array}{c}.018 \\
(.002)^{* * *}\end{array}$ & & $\begin{array}{c}.008 \\
(.003)^{* * *}\end{array}$ \\
\hline Market Capitalization & & $\begin{array}{c}0 \\
(.00007)^{* *}\end{array}$ & & $\begin{array}{c}-.0003 \\
(.00008)^{* * *}\end{array}$ \\
\hline Obs. & 20686 & 20686 & 20686 & 20686 \\
\hline$R^{2}$ & .111 & .114 & .13 & .133 \\
\hline
\end{tabular}




\begin{tabular}{|c|c|c|c|c|}
\hline \multirow[b]{2}{*}{ Const. } & \multicolumn{2}{|c|}{ Leverage 1} & \multicolumn{2}{|c|}{ Leverage 2} \\
\hline & $\begin{array}{c}.279 \\
(.008)^{* * * *}\end{array}$ & $\begin{array}{c}.313 \\
(.009)^{* * *}\end{array}$ & $\begin{array}{c}.241 \\
(.003)^{* * *}\end{array}$ & $\begin{array}{c}.184 \\
(.008)^{* * *}\end{array}$ \\
\hline Tangibility & $\begin{array}{l}-.022 \\
(.005)^{* * *}\end{array}$ & $\begin{array}{l}-.022 \\
(.005)^{* * *}\end{array}$ & $\begin{array}{l}.127 \\
(.026)^{* * *}\end{array}$ & $\begin{array}{c}.127 \\
(.026)^{* * *}\end{array}$ \\
\hline Profitability & $\begin{array}{c}-.001 \\
(.001)\end{array}$ & $\begin{array}{c}-.001 \\
(.001)\end{array}$ & $\begin{array}{c}-.001 \\
(.001)\end{array}$ & $\begin{array}{c}-.001 \\
(.001)\end{array}$ \\
\hline Log assets & $\begin{array}{c}-.015 \\
(.0002)^{* * *}\end{array}$ & $\begin{array}{c}-.015 \\
(.0002)^{* * *}\end{array}$ & $\begin{array}{c}.011 \\
(.0004)^{* * *}\end{array}$ & $\begin{array}{c}.011 \\
(.0004)^{* * *}\end{array}$ \\
\hline Industry leverage & $\begin{array}{c}.764 \\
(.009)^{* * *}\end{array}$ & $\begin{array}{c}.764 \\
(.009)^{* * *}\end{array}$ & $\begin{array}{c}.390 \\
(.023)^{* * *}\end{array}$ & $\begin{array}{c}.389 \\
(.023)^{* * *}\end{array}$ \\
\hline GDP growth & & $\begin{array}{c}-.001 \\
(.0002)^{* * *}\end{array}$ & & $\begin{array}{c}-.004 \\
(.0003)^{* * *}\end{array}$ \\
\hline Inflation & & $\begin{array}{c}-.003 \\
(.0002)^{* * *}\end{array}$ & & $\begin{array}{c}.001 \\
(.0004)^{* * *}\end{array}$ \\
\hline Corporate tax & & $\begin{array}{c}-.00008 \\
(.00006)\end{array}$ & & $\begin{array}{l}.0001 \\
(.00009)\end{array}$ \\
\hline Savings & & $\begin{array}{l}-.0005 \\
(.0002)^{* *}\end{array}$ & & $\begin{array}{c}.003 \\
(.0004)^{* * *}\end{array}$ \\
\hline Market Capitalization & & $\begin{array}{c}-.00009 \\
(9.30 \mathrm{e}-06)^{* * *}\end{array}$ & & $\begin{array}{c}-.0002 \\
(.00002)^{* * *}\end{array}$ \\
\hline Obs. & 3035109 & 3035109 & 3035109 & 3035109 \\
\hline$R^{2}$ & .059 & .059 & .09 & .09 \\
\hline
\end{tabular}


Table 9 - Broad LeVerage Regression in 1995-2002, ACross Size Classes

\begin{tabular}{lccc} 
& PANEL A - LISTED FIRMS & \\
\hline \hline & Size $1-3$ & Size 4 & Size 5 \\
\hline Const. & 1.182 & .064 & -.032 \\
& $(.264)^{* * *}$ & $(.111)$ & $(.043)$ \\
Tangibility & -.121 & .107 & .023 \\
& $(.102)$ & $(.027)^{* * *}$ & $(.016)$ \\
Profitability & -.074 & -.081 & -.143 \\
& $(.016)^{* * *}$ & $(.014)^{* * *}$ & $(.031)^{* * *}$ \\
Log assets & -.07 & .007 & .018 \\
& $(.018)^{* * *}$ & $(.009)$ & $(.002)^{* * *}$ \\
Industry leverage & .16 & .707 & .79 \\
& $(.16)$ & $(.069)^{* * *}$ & $(.055)^{* * *}$ \\
Obs. & 1086 & 6269 & 13331 \\
$R^{2}$ & .128 & .093 & .123 \\
\hline \hline
\end{tabular}

Notes: ${ }^{* * *},{ }^{* *}$, and ${ }^{*}$ denote significance at the 1,5 and 10 percent level, respectively. Standard errors are based on clustering across firms. All regressions include country and year dummies.

PANEL B - UNLISTED FIRMS

\begin{tabular}{lccccc}
\hline \hline & Size 1 & Size 2 & Size 3 & Size 4 & Size 5 \\
\hline Const. & .355 & .643 & .376 & -.058 & -.11 \\
& $(.012)^{* * *}$ & $(.019)^{* * *}$ & $(.018)^{* * *}$ & $(.02)^{* * *}$ & $(.033)^{* * *}$ \\
Tangibility & .03 & -.061 & -.069 & -.019 & .032 \\
& $(.003)^{* * *}$ & $(.003)^{* * *}$ & $(.003)^{* * *}$ & $(.01)^{* *}$ & $(.006)^{* * *}$ \\
Profitability & -.0007 & -.615 & -.001 & -.227 & -.253 \\
& $(.0005)$ & $(.051)^{* * *}$ & $(.002)$ & $(.086)^{* * *}$ & $(.075)^{* * *}$ \\
Log assets & .0006 & -.043 & -.026 & .004 & -.005 \\
& $(.0009)$ & $(.002)^{* * *}$ & $(.002)^{* * *}$ & $(.001)^{* * *}$ & $(.001)^{* * *}$ \\
Industry leverage & .506 & .578 & .743 & 1 & 1.193 \\
& $(.013)^{* * *}$ & $(.014)^{* * *}$ & $(.014)^{* * *}$ & $(.019)^{* * *}$ & $(.037)^{* * *}$ \\
Obs. & 853024 & 632717 & 737598 & 681042 & 130728 \\
$R^{2}$ & .022 & .159 & .079 & .088 & .075 \\
\hline \hline
\end{tabular}

Notes: ${ }^{* * *},{ }^{* *}$, and ${ }^{*}$ denote significance at the 1,5 and 10 percent level, respectively. Standard errors are based on clustering across firms. All regressions include country and year dummies. 
APPENDIX TABle 1 - Representativeness of DATA, AMADEUS DATA VERSUS "ENTERPRISES IN EUROPE"

\begin{tabular}{lrr}
\hline \hline Country & $\begin{array}{r}\text { Correlation of size distribution } \\
\text { across industries }\end{array}$ & $\begin{array}{r}\text { Correlation of } \\
\text { industry distribution }\end{array}$ \\
\hline Belgium & .995 & .857 \\
Finland & .975 & .601 \\
France & .989 & .552 \\
Germany & -.746 & .000 \\
Italy & .966 & .564 \\
Portugal & .844 & .773 \\
Spain & .991 & .640 \\
Sweden & .986 & .792 \\
United Kingdom & .492 & .148 \\
\hline
\end{tabular}

NoTES: Size and industry distributions are calculated based on the number of firms. Firms were divided into 3 size classes: 10-49, 50-249, and more than 250 employees. Industries were divided into 6 groups: 10-41 Industry and Energy, 45 Construction, 50-55 Trade and Hotels and Restaurants, 6064 Transport and communication, 74 Other Business Activities, and 70-73, 85, 90, 92, 93 Other Services. Amadeus data is for 1997. EU data is for 1997 except for France, Italy, Portugal, and Sweden for which 1996 data were used. 
Individual researchers, as well as the on-line and printed versions of the CERGE-EI Working Papers (including their dissemination) were supported from the following institutional grants:

- Center of Advanced Political Economy Research [Centrum pro pokročilá politicko-ekonomická studia], No. LC542, (2005-2009),

- Economic Aspects of EU and EMU Entry [Ekonomické aspekty vstupu do Evropské unie a Evropské měnové unie], No. AVOZ70850503, (2005-2010);

- Economic Impact of European Integration on the Czech Republic [Ekonomické dopady evropské integrace na ČR], No. MSM0021620846, (2005-2011);

Specific research support and/or other grants the researchers/publications benefited from are acknowledged at the beginning of the Paper.

(c) Karin Jõeveer, 2005

All rights reserved. No part of this publication may be reproduced, stored in a retrieval system or transmitted in any form or by any means, electronic, mechanical or photocopying, recording, or otherwise without the prior permission of the publisher.

Published by

Charles University in Prague, Center for Economic Research and Graduate Education (CERGE) and

Economics Institute (EI), Academy of Sciences of the Czech Republic

CERGE-El, Politických vězňu 7, 11121 Prague 1, tel.: +420 224005 153, Czech Republic.

Printed by CERGE-EI, Prague

Subscription: CERGE-El homepage: http://www.cerge-ei.cz

Editors: Directors of CERGE and EI

Managing editors: Deputy Directors for Research of CERGE and EI

ISSN 1211-3298

ISBN 80-7343-077-0 (Univerzita Karlova v Praze, CERGE)

ISBN 80-7344-066-0 (Národohospodářský ústav AV ČR, Praha) 
CERGE-EI

P.O.BOX 882

Politických vězňů 7

11121 Praha 1

Czech Republic http://www.cerge-ei.cz 